\title{
PUBLIC HEALTH AND SOCIAL JUSTICE Toward ethical sustainability in healthcare and research
}

Fernando Lolas*

\begin{abstract}
This paper puts forward the notion of ethical sustainability as the manifestation of moral values in public health policy. The most relevant of these values is that of justice, which is interpreted as fairness and qualified according to the type of society: Gemeinschaft, where social relations are ends in themselves, and Gesellschaft, where social relations are means to individual ends. Bioethics, as the dialogical construction of the moral universe and the support of moral imagination, is depicted both as a discourse and as a tool for improving the commonwealth.
\end{abstract}

Key words: Bioethics, public health, social justice, ethical sustainability

\section{SALUD PÚBLICA Y JUSTICIA SOCIAL Hacia una sustentabilidad ética en atención de salud e investigación}

Resumen: Este artículo desarrolla la noción de sustentabilidad ética como manifestación de valores morales en las políticas de salud pública. El más relevante de tales valores es el de la justicia, interpretada como equidad y cualificada según el tipo de sociedad: Gemeinschaft, en la cual las relaciones sociales son fines en sí mismos, y Gesellschaft, en la cual las relaciones sociales son medios para fines individuales. La bioética, como construcción dialógica del universo moral y sustento de la imaginación moral, se presenta como discurso y como una herramienta para mejorar el bien común.

Palabras clave: Bioética, salud pública, justicia social, sustentabilidad ética

\section{SAÚDE PÚBLICA E JUSTIÇA SOCIAL Para a sustentabilidade ética no cuidado à saúde e na pesquisa}

Resumo: Este artigo desenvolve a noção de sustentabilidade ética como manifestação de valores morais nas políticas de saúde pública. O mais relevante de tais valores é o da justiça, interpretada como equidade e qualificada segundo o tipo de sociedade. Gemeinschaft, em que as relações sociais são fins em si mesmos, e Gesellschaft, em que as relações sociais são meios para afins individuais. A bioética, como construção dialógica do universo moral e sustento da imaginação moral, apresenta-se tanto como discurso, bem como uma ferramenta para melhorar o bem comum.

Palavras chave: Bioética, saúde pública, justiça social, sustentabilidade ética

\footnotetext{
Director, Bioethics Unit PAHO/WHO.
}

Correspondence: lolasf@chi.ops-oms.org 


\section{Health as a multilayered construct}

A basic source of ethical conflict and tension exists between individual needs or desires and the public good. Theories about priorities and ways of resolving this conflict are central to any discussion on health and healthcare.

Political liberals tend to promote a rights model of health care. According to this model, there is an individual right to health and a corresponding right to equal access to health care. Communitarians tend to view sickness and death as shared threats to human life, a basic condition of human existence requiring a shared response. Solidarity as a basic value is treated differently in the context of these two theoretical positions. In the first, it is a convenience calculation ("every good egoist is an altruist”), in the second it constitutes a precondition for collective life ("the good of society is superior to the good of individuals”).

Health is typically a "layered", complex, construct. At the microlevel, that is, at the level of biochemical and physiological processes "within" biological organisms, it is difficult to define, with no meaning distinct from statistical normalcy, and susceptible of intervention for correcting values which fall outside a normal range. At the macrolevel, health is the aggregate of societal effects that promote or maintain well-being of individuals but at the same time promote, enhance or improve social capital, the web of creative relations between people. It is at the intermediate level, the level of individual health, where medical action, death and suffering take place. The level of the person is endowed with meaning and constitutes the privileged locus of moral action. Medicine has been concerned mostly with this intermediate level at the risk of neglecting the "common space" of societal health. At some point in the history of the health sciences, and influenced by the nascent disciplines of the social sciences, some authors spoke about "sick societies"(1). This soon proved to be a metaphorical way of referring to states of distress of individuals in groups. Society, as such, cannot become ill in the sense that an organism gets ill, unless the metaphor equating society with the body is pushed too far, as Rudolph Virchow did when he compared medicine to politics and cells to individual human beings.

That health cannot be defined below the level of the individual organism and is difficult to ascertain at the societal level supports the contention that equating health with good occurs only at the human level. It is, in fact, an evaluative act, not a neutral or natural determination. In 1941, Henri Sigerist wrote that "a healthy individual is a man who is well balanced bodily and mentally, and well adjusted to his physical and social environment... Health, therefore, is not simply the absence of disease; it is something positive, a joyful attitude towards life, and a cheerful acceptance of the responsibilities that life puts upon the individual”(2). Undoubtedly, this position influenced the definition adopted by the First World Assembly of WHO and the drafters of that definition stated that health is "a state of complete physical, mental and social well-being and not merely the absence of disease or infirmity" $(3,4)$. Good is no natural category, however, in the sense that molecules or cells are, and evaluative acts can be performed on an indefinite number of life domains, such as the spiritual, which can also be considered part of the definition of health. Thus, individual health as a value is more an ideal (or "virtue", areté, excellence) to aspire to, rather than a description of a state or a factual determination. More a quality of life than a scientific object of study, health has become difficult to measure and indicators are difficult to develop. 


\section{Bioethics and public health}

This difficulty in definition and operationalization of the health construct is evident in the field of public health. Its disciplinary independency started with descriptive sciences, such as epidemiology, whose task soon was expanded to providing help in decision-making processes and as a useful device for making recommendations on how to improve people's lives. It also became apparent that quality of life, a more inclusive concept than health itself and scientifically more neutral, could be related either to individual health aspects or to the contexts (physical, social and symbolic) in which persons live. Public health may be said to reflect this contextual aspects of health and the realm of interventions at the macro level. As an interventional strategy, public health refers to those activities performed by the organized social body to attain and maintain the culturally appropriate level of functioning of its members and of the group.

Bioethics in the sphere of public health expands the dialogical participation of moral actors to the health consequences of interventions at the contextual level, that is the web of relations and interactions between human bodies, be they physical or abstract and symbolic. Whereas autonomy, beneficence and non-maleficence are principles with evident application at the intermediate level of the health construct (the level of individual persons), justice is undoubtedly the principle most relevant to planning and intervention at the macro, societal or public level.

The Kantian categorical imperative implies that the maxim by which a person directs his/ her life should be generalizable to society as a whole. In this sense, a just action is an action which assures continuity and wellness of society and not only of a few members in it. It is a prospective value, its existence provides the foundation for social life.
As the discussion below shows, there is both a formal and a material aspect to justice and there exist many forms in which the principle or value is expressed in societies. Goal-based, duty-based and rights-based considerations for the fulfillment of this value or principle are useful for devising (or "inventing”) those rules which will lend presence to justice in human affairs, modulated by cultural imprint and traditions. In any context, it may be observed that individual moral agents reach a reflective equilibrium between their own personal experiences (cases of consciousness), the principles explicitly supported by people and those mores, traditions and customs which implicitly modulate moral action.

It may be said that the principles of autonomy, beneficence, non-maleficence and justice, among others, can be discerned in all known societies. The precise architecture of their relations is, nevertheless, different in different societies. This is similar to the principle of isomerism in chemistry, where compounds which are similar in general formulae may be different in structure.

\section{Justice and society}

Justice is a property of social systems, in much the same way as truth is a property of systems of thought (Rawls). The definition of group and social system is not, however, a simple one.

It has proven useful to distinguish, with the sociologist Tönnies, between Gemeinshaft and Gesellschaft. The first is based on face-to-face contacts and comprises small groups. The essential aspect is that social relations between persons are ends in themselves. In the second type of social organization, typical of larger societies with differentiation by work and classes of individuals, human relations are mostly means to accomplish personal or social 
goals. It might be said that Gemeinschaft is a group geared towards human relations and Gesellschaft is a group oriented towards impersonal social tasks. This type of society, characteristic of Western industrialized nations, was made responsible for alienation and other social ills and concentrated the criticism from the social reformers who founded the discourse of the social sciences in the XIXth and XXth century.

Justice is a property of both types of social systems. Justice may be said to imply the fair distribution of good in society. The type of justice most appropriate for Gemeinschaft is commutative or retributive justice, the essence of which is the exact retribution of what is given. Primitive forms of legal systems indicate that penalties are proportional to, if not equal to, offences. Contracts are based on trust and reciprocal agreement in exact proportion of what is exchanged. Common morality, or morality in the narrow sense, is closely associated with custom and tradition.

The form of justice most appropriate for Gesellschaft is distributive justice. The commutative form does not disappear. It finds expression in many different areas, such as penal and contractual law. In healthcare the question is how can society provide equal opportunities to its members and how fair the distribution of social goods can be. Health as such cannot be reduced to a commodity that can be sold, bought or exchanged, but healthcare and its associated services are subject to market principles as any other service.

Health, as rightly pointed out by many, is a personal construction not reducible to medical interventions, and depends on social, personal, spiritual and economic factors. In this regard, it is useful to remember that development and maintenance of healthcare systems require acknowledging a "clash of rationalities”. A ratio- nality is a set of principles for administering and expanding a technology (technologies like the productive ones, the semiotic ones, power technologies and technologies of the self are part of the operation of healthcare systems) and it exhibits a tendency to monopolize the whole system of thought (technocratic turn of modern societies). Economic rationality, for instance, is based on the notion of scarcity and aims at maximizing efficiency and efficacy in the use of resources. Therapeutic rationality, on the other hand, is oriented towards alleviating or ameliorating deficits. Scientific rationality is aimed at renovating disciplines and producing generalizable knowledge.

The technocratic turn of modern societies has led to a unilateral development of privileged forms of rationality which become monopoles. The notion of sustainability, for instance, is associated mostly with economic rationality. However, there are also other forms of sustainability, each associated with a different rationality. We tend to speak of "ethical sustainability" to refer to a form of social behavior appropriate for the challenges of moral wisdom.

In relation to healthcare and justice, irrespective of the form this principle adopts in a particular society (it is always a formal, not a material principle, and has to be filled with content in a given tradition), the larger the society the greater the need for "moral imagination" from its members. Moral imagination, in large and impersonal societies, replaces face-to-face contacts and immediate consequences of actions with anticipation of effects and empathic understanding of the motives people have for behaving the way they do. Moral imagination is also the ability for inventing moral rules, which constitute the "practical translation" of values and principles into everyday practice. Values and principles are universals of meaning, practical rules are concrete instances. 


\section{Towards bioethical sustainability}

Daniel Callahan has forcefully put forward the notion of a sustainable medicine(5). The idea of sustainability is borrowed from the economic sciences and implies the renovation and affordability of decisions in the future. His reflections deal with the requisites the social institution of medicine should have for being able to meet the goals society ascribes to it. He suggests that indefinite progress, unending technological innovation, and the perpetual search for perfection militate against universal coverage, equity of access, and affordability. Even in economic terms, his analysis seems -or may be interpreted as- conflicting with the main trends of Western medicine. We need, Callahan says, a steady-state medicine, a sustainable social practice that perhaps will not be the best possible in technological terms but will be attainable, reasonable, and affordable. His is a plea for sobriety and self restraint. He emphasizes the fact that technology-driven medicine has been obsessed with means and that a fresh look at this institution should examine its goals. In a groundbreaking project entitled precisely "The goals of medicine", a number of scholars from different countries examined what the perennial goals of social practices may be and how badly needed a reflection on them was in times of reform. From that analysis, several propositions can be formulated for the future of healthcare and several suggestions for further research at the interface between philosophical analysis and empirical social research.

Ethical sustainability as a concept is deeply rooted in a profound consideration of justice in all its forms. The challenge ahead lies in recapturing those positive aspects of small societies (Gemeinschaft) in a reformulated Gesellschaft that has learnt to appreciate that progress without humanity is no progress at all. It may appear as a truism but experience shows that social systems built around technology and its mores tend to free themselves from external restraints and become autonomous. The problems they create are of a kind which technology itself cannot address, even less solve.

The reason why we should explore the relation between technology and health is that technology is one of the forces behind contemporary political power, the market, and the idea of indefinite progress. Up to now, the technological divide (in its form of digital divide, or of economic prosperity) is clearly a factor in the increasing inequity of access to life opportunities and to healthcare which plagues Latin American countries and other regions of the world. The more money is invested in high tech medicine, the deeper the difference between the "have" and the "have not", the more evident the spiraling of injustice which, in naive hands, may lead to antiscience or antitechnology movements. Globalization has come to mean power of those who possess technoscience and, along with respect, it commands distrust and antagonism.

A technology-driven progress is not in itself dangerous or even negative. It is the uses of technology which should be viewed against a deep reflection on justice and equity. Goal-based considerations may suggest that we should not stop research and science, for some day their benefits will be accessible to all. This has not proved to be true up to now. Duty-based considerations imply that those who have should share with those who do not have. Every good egoist, the saying goes, should be an altruist. However, blind quest for profit may obliterate any good use of technology based on duty considerations. And finally, rights-based considerations, although appealing to those who try to defend them, are usually less compelling for rights than "centripetal factors" are. They are located in persons but do not emanate from persons, since they have to be recognized by others to be fully effective. 
Duties, on the contrary, radiate from the person Violations of human rights occur everywhere and and are his/her sole responsibility. An unfulfilled at all times. This implies that rights need a twoduty engenders guilt. A right not respected pro- $\quad$ tied system, their presence and the "good will" duces anger and shame. As the historical record to respect them, whereas an accepted duty is a shows, only by the force of law and convention force in itself for the person who recognizes it can rights be ascertained and made respectable. as personal.

\section{References}

1. Halliday J. Psychosocial Medicine. A Study of the Sick Society. New York: Norton; 1948.

2. Sigerist HE. Medicine and Human Welfare. New Haven: Yale University Press; 1941.

3. World Health Organization. Constitution. Geneva: WHO; 1948.

4. Chatterji S, Ustün BL, Sadana R, et al. The conceptual basis for measuring and reporting on health. Global Programme on Evidence for Health Policy. Discussion Paper No. 45. Geneva: WHO; 2002.

5. Callahan D. False Hopes. New York: Simon \& Schuster; 1998. 